solution, there is a need to debate other ways of reaching the same goal. Those who have misunderstood our proposal are detracting from this important issue.

SIMON BRTTTEN MARK $S$ WHITELEY PETER F FOX MARK I GOODWIN MICHAEL HORROCKS

University Department of Surgery, Royal United Hospital Trust,

Bath BA1 3NG

1 Britten S, Whiteley MS, Fox PF, Goodwin MI, Horrocks M Annual influx of temporary residents to the Glastonbury Festival. $B M \mathcal{F}$ 1993;307:561. (28 August.)

Chambers J, Guly $H$. The impact of a music festival on local health services. Health Trends 1991;23:122-3.

3 Sanders AB, Criss E, Steckl P, Meislin HW, Raife J, Allen D. An analysis of medical care at mass gatherings. Ann Emerg Med 1986;15:515-9.

4 Howes C. Medical treatment at the Glastonbury Festival. $B M$ 1993;307:865. (2 October.)

5 Pattison G. Medical treatment at the Glastonbury Festival. $B M f$ 1993;307:865. (2 October.)

\section{Funding policies for HIV and AIDS}

EDrTOR,-As service providers working in an area with a high prevalence of HIV infection we were concerned by Mark McCarthy and Sarah Layzell's comments in their article on funding policies for HIV and AIDS. ${ }^{1}$ The sexually transmitted disease service in Britain is based on the fundamental principle of open access. This well proved public health approach is the envy of the world and should not be dismantled because of the purchaserprovider split; block funding to provide a service to all comers regardless of residence must continue.

Genitourinary physicians do not, and do not wish to, provide primary health care. Liaison and shared care with general practitioners are recognised as important parts of the management of HIV positive patients. As a direct result of our commitment to support local services, $94 \%$ of our patients with far advanced disease are managed by general practices with back up from our palliative care team. Over $60 \%$ of patients have died at home and $90 \%$ died where they had said that they wanted to die. No general practitioner was prepared to manage these complex cases without support Furthermore, 200 interventions prevented admission to hospital.

McCarthy and Layzell confuse the debate about the balance of funding between prevention and treatment by implying that the national situation can be compared with that in Camden and Islington Health Authority. We treat roughly a tenth of the cases of AIDS in England and are therefore funded to provide services to a high proportion of people who are not residents, whereas money for prevention is meant to fund only work with the resident population. Money allocated under "HIV prevention" accounts for only a small part of the money spent on prevention. "HIV funding" for drug services is primarily used to fund needle exchanges. Genitourinary medicine clinics have a key role in preventing HIV infection as attendance at a clinic is highly correlated with high risk sexual behaviour; thus a percentage of their funding could legitimately be billed as expenditure on prevention.

McCarthy and Layzell lament that Camden and Islington Health Authority has only just developed an HIV prevention strategy. This is one of the first strategies to be developed nationally and has been cited as a model of good practice by the Department of Health and has achieved national recognition.

As McCarthy is a purchaser of health care we would have expected the authors to advocate choice for patients, but they seem to deplore our attempts to provide services that are popular with patients. Why make the distribution of cases of
HIV infection and AIDS as thin as possible when specialist services can at one visit provide an experienced doctor, health adviser, nurse, psychologist, specialist pharmacist, etc? We believe that HIV positive patients have shown their preference by continuing to attend large genitourinary medicine clinics in central London for their care.

MICHAEL ADLER ERICA ALLASON-JONES PATRICK FRENCH

ROB GEORGE

James Pringle House,

Middlesex Hospital,

London W1N 8AA

1 McCarthy M, Layzell S. Funding policies for HIV and AIDS time for change. BMf 1993;307:367-9. (7 August.)

\section{Juniors and consultants should follow guidelines}

EDrTOR,-Alastair McColl's suggestion that guidelines may be more useful to junior than senior staff raises the question of who should be the target of clinical guidelines. ${ }^{1}$ Hospital consultants vary widely in their adherence to agreed standards..$^{23} \mathrm{At}$ a recent seminar on the development of guidelines, held at a local district general hospital, a consultan said that he would be happy to have guidelines for his NHS practice but not for his private work. The "incredibly powerful lever of contracting" has yet to influence private practice in Britain, unlike in the United States, where the demands of insurance companies have been one of the main forces driving the development of guidelines. ${ }^{45}$

Clinical guidelines are increasingly being developed from systematic reviews of published data and must be seen as defining acceptable and appropriate standards of care. They are surely appropriate not only for junior hospital staff but also for consultants in their NHS and private work This aspect of the debate on guidelines has been neglected in Britain.

HRIS GRIFFITHS

Hackney Collaborative Clinical Guidelines Project,

Department of General Practice,

St Bartholomew's Medical College,

London EC1M 6BQ

1 McColl A. Implementing clinical guidelines. BMf 1993;307:6789. (11 September.)

2 Bell D, Layton A, Gabbay J. Use of a guideline based questionnaire to audit hospital care of acute asthma. $B M \mathcal{J}$ questionnaire to

3 Dunn RB, Lewis PA. Compliance with standardised assessment scales for elderly people among consultant geriatricians in Wessex. $B M 7$ 1993;307:606.

4 Haines A, Feder G. Guidance on guidelines. BMF 1992;305: 785-6.

5 Farmer A. Medical practice guidelines: lessons from the United States. $B M{ }^{1} 1993 ; 307: 313-7$.

\section{Drug regimens that break a country's drug laws}

EDrToR,-Doctors in Britain have unrivalled autonomy in their right to exercise clinical judgment in their treatment of drug addicts. This privilege must, however, be treated with care, otherwise the eventual result will be local and international calls for new controls on all members of the medical profession.

A citizen who was a resident of the United States contacted us earlier this year, asking us to take over his care from another doctor in Britain. On making inquiries with this doctor and the patient we learnt that the patient had been travelling between the United States and Britain and had received prescribed supplies of diamorphine (heroin) and cocaine-both drugs prohibited in the United
States regardless of any claimed medical indication. A daily dose of $900 \mathrm{mg}$ heroin had been prescribed. Other doctors (in Britain and the United States) had judged his opiate requirement in the preceding months and years to be about one tenth of this dose, or up to $80 \mathrm{mg}$ methadone daily. Pharmaceutical cocaine had also been prescribed, making this American visitor one of perhaps only about a dozen people in Britain (and hence in the world) to receive prescribed cocaine in the name of treatment of addiction.

The individual decisions of different doctors in Britain will inevitably vary. But if this privileged autonomy is not treated with sensitivity by doctors and patients we should not be surprised if there are calls for increased regulation, control, and conformity. Indeed, the existing controls on prescribing heroin and cocaine were introduced largely in response to just such prescribing by a few doctors in the mid-1960 $\mathrm{s}^{1}$ and to a population of addicts that included several hundred North American narcotic addicts who had been drawn to Britain by the more liberal prescribing policies. ${ }^{24}$

To institute drug regimens that clash so fundamentally with the drug laws and treatment programmes of the country to which the patient will soon return is to invite calls for international harmonisation from the rest of Europe and, particularly, the United States. Paradoxically, it would result in more calls for prohibition and curbs on the clinical freedom for everyone, to the detriment of the "British system" as a whole.

JOHN STRANG MICHAEL FARRELI

National Addiction Centre,

Maudsley Hospital and Institute of Psychiatry,

London SE5 8AF

1 Interdepartmental Committee on Drug Addiction. Second report. London, HMSO, 1965.

2 Spear HB. The growth of heroin addiction in the United Kingdom. I Addiction 1969;64:245-55.

3 Zacune J. A comparison of Canadian narcotic addicts in Great Britain and Canada. Bulletin on Narcotics 1971;23:41-9.

4 Blackwell, J. The saboteurs of Britain's opiate policy: overprescribing physicians or American-style junkies? Int $\mathcal{f}$ Addict 1988:23:517-26.

\section{Seeing is believing}

EDrToR,-In their comments on Minerva's picture of an ingested coin visible in an anteroposterior radiograph of the neck John Baillie and Malcolm S Branch state that "as small children are unreliable historians, any child under the age of 5 being assessed for foreign body ingestion should have plain radiography from the base of the skull to the anus." 2

Most ingested foreign bodies that pass beyond the gastro-oesophageal junction traverse the rest of the gastrointestinal tract uneventfully. Given that this is the case, I believe that a radiograph of only the chest (including the neck) is required to ensure that the foreign body is not impacted above the gastro-oesophageal junction. Radiographs of the abdomen are indicated only if the child develops symptoms suggesting complications, such as intestinal obstruction, or if the foreign body is such that the likelihood of complications is high and its removal is desirable.

On average the dose of radiation required for a posteroanterior radiograph of the chest is $0.3 \mathrm{mGy}$ while that of an anteroposterior radiograph of the abdomen is $10 \mathrm{mGy}$. Use of this strategy would therefore limit exposure to $x$ rays in this not insignificant proportion of children.

Accident and Emergency Department,

CAROLINE PARK

Selly Oak Hospital,

Birmingham B29 6JD

Minerva pictures. $B M 7$ 1993;307:273. (24 July.)

2 Baillie J, Branch MS. Seeing is believing. BMF 1993;307:684-5. (11 September.) 